\title{
The translations into Romanian of the Austrian laws for the province Bukovina (1775-1918)
}

\author{
Iulia Elena Zup* \\ Faculty of Law, "Alexandru Ioan Cuza" University, Bd. Carol I 11, 700506 Iași, Romania
}

\section{Article info}

History:

Received February 6, 2019

Accepted February 26, 2019

Published May 7, 2019

Key words:

translation

stylistics

lexical borrowings

\begin{abstract}
This paper explores the context in which the laws of the Habsburg Empire were translated into Romanian for the province Bukovina and identifies three periods of translation corresponding to the major administrative transformations and to the evolution of the Romanian juridical style. The role of the translations is analysed in the process of cultural transfer between the centre and the periphery, the main focus is on the linguistic strategies employed by the translators who had thus to compensate for the still undeveloped Romanian legal thinking and terminology. The impact of the translations on the cultural and linguistic becoming of Romania is evaluated.
\end{abstract}

\section{Introduction}

Since its annexation by the Habsburg Empire in 1775, the Bukovina space is no longer a homogeneous one, but one separated and divided by Moldavians and German speakers, by boyars and local peasants, civil servants and officers of the military administration, by German emigrants and Jews. The Empress Maria Theresia's measures of centralisation of the administration from the second half of the $18^{\text {th }}$ century imply also the exclusive use of German in all state institutions. These measures of centralisation and simplification of the administration are continued by her son, the Emperor Joseph II; to this purpose, he introduces in 1784 German as the official language, the language of the administration and justice, in the whole empire, thus replacing Latin.

From the functional asymmetry of the use and prestige of the languages-German, Romanian, Ruthenian-in Bukovina results a hierarchy of languages, which reflects the balance of power. In the context of these linguistic constellations, there are differences in the attitude towards different fields of use, the conflicts appearing especially in the fields of education or administration, more rarely in the medical field, for example. Thus, the translation process served not only as a means of communication between cultures, but also represented a milieu for the cultural transfer, contributing immensely to the construction of the cultures of the Habsburg space. Through translation, continuous reinterpretations and transformations are reached, which make the receiving culture decisively more dynamic and lead at the same time to ruptures, all these processes strengthening or weakening the asymmetric balance of power. In the analysis of the translations, decisive is to what extent did the processes of discursive transfer between the two cultures take place. Another important element is the hierarchic relationships between the engaged actors. The balance of power conditions the communicative processes at all levels; it starts with tensions between the social groups and enter during the communicative process in the conflicts between nationalities, which influence decisively the mechanisms of carrying out the communication. The conflicts between nations result in an increase in the national conscience, which calls for the creation of original cultural products. On the background of the social movements of 1848, the imperial constitutions from the $25^{\text {th }}$ of April 1848 , respectively the $4^{\text {th }}$ of March 1849 , comprised liberal regulations regarding the languages of the Empire, guaranteeing all citizens in Article 4 the inviolability of the nation and the national languages.

*Email address: iuliazup@gmail.com. 
Iulia Elena Zup

Bukovina represents a space of the overlapping of cultures, where the negotiations between cultures takes place, where asymmetric forces meet, the dissonance and what is not or cannot be articulated. The character of construct of the translation starts from this conception about culture, which takes into consideration the multifaceted process resulting from the cultural contact between the meaning and the new contextualisation. The character of dialogue, polyphony, of interaction of the translation contributes to the construction of the receiving culture, allowing modifications, renewal and transformations. Thus, the Bukovina culture can be interpreted also as result of the translation processes.

Starting from the categories introduced by Kremnitz (1994, p. 24, 38) regarding bilingualism, namely the symmetric bilingualism, which means similar competences in both languages, and the asymmetric bilingualism, which refers to competences more complex in one language than in the second one, we can say that, at the beginning of the Habsburg domination, the Bukovina space is characterized by a symmetric bilingualism, in time progressing - through the introduction of German in the administration, the setting up of German schools and the access to studies at the University of Vienna-towards a symmetric bilingualism. Equally there are relevant the concepts of instrumental or functional bilingualism, meaning the extension of the expression competences in the other language, and integrative bilingualism, meaning the integration, by learning or studying thoroughly the second language, in a (new) society or social category. The access to the structures of power, to a hierarchic evolution is conditioned by the learning of the second language, that of the centre. The bilingualism is a phenomenon which exceeds social boundaries, the linguistic contact effecting interferences, linguistic borrowings and changes.

\section{Translation periods}

The intense translation activity had several causes: the official language was German, the laws had to be known by all inhabitants of the empire, the new constitutional regulations from 1849 provided for the raise of the local languages to official rang, and thus the obligation to publish the laws in all languages of the empire. The translations for Bukovina can be delimited and analysed on three periods, which correspond to the administrative periods, as well as the periods of the evolution of the Romanian legal style (Zup, 2015b):

2.1. In the first period, between 1775 and 1848 , Bukovina is under military administration immediately after the annexation (1775-1786), then part of the Kingdom of Galicia and Lodomeria (1786-1849). As a result of introducing German as the official language, in the first period are translated the acts regarding Bukovina's incorporation, followed by the most important laws, which were translated in Romanian under the supervision of Vasile Balş by the translators Ion Budai-Deleanu and Georg Oechsner. Other administrative documents and orders published in form of leaflets were translated by civil servants and clerks. The translations of this period belong to an era of transformations on linguistic level, the observation of the limited expression possibilities of the Romanian language in comparison to the West-European idioms (by observing the lack of expressions and terms equivalent to those in German, in our case) generating an intense activity of language cultivation (Minuț \& Lihaciu, 2014, p. 92). One tried to overcome these shortcomings by writing dictionaries and grammars or other linguistic works. The awareness of the necessity of synchronizing the endeavours of writing in Romanian with the West-European models marks the entering of our culture in the modern period.

2.2. In the second period, between 1849, when Bukovina wins its autonomy within the Austrian Empire and becomes a duchy, and 1918, when it became part of Kingdom of Romania, many translations are carried out, especially those of the constitutional acts from the beginning of the period, of the civil, criminal and procedure codes. In this period there are published the Romanian version of Reichsgesetzblatt - Foaia legilor imperiale [Journal with the Empire's legislation] and the journal of Bukovina's local government containing laws and orders, Landesgesetzblatt - Foaia legilor provinciale, but also some dictionaries and reference works for the civil servants in the administration and translators. A new development of the legal 
language takes place now, alongside with the unification of the legislation in the Romanian principalities through the introduction of the criminal and civil codes in 1864, also known as "Cuza's codes".

2.3. In the period between 1918 and 1938, in the region Bukovina still remains in force the majority of the Austrian regulations, which are translated now for more readers, even in other regions of the Kingdom of Romania. Moreover, the Romanian laws are translated into German for the German speaking population in Bukovina. From a linguistic point of view, the tendency is to unify the legal language. The translation activity in this period can be analysed from a postcolonial perspective regarding the late consequences of the colonisation process.

In regard to the terms used in the Romanian texts, for the German specialty words, the translator makes use of:

- legal terms of strict specialty which can be considered savant borrowings (single area of meaning);

- words from the general vocabulary used as legal terms (polysemy) - here two means are used: the insertion of words in specialized legal syntagms and the redefining within the text.

The new introduced words after the model of the German source text are of two types:

a) neologisms, whose meanings are explained by some translators through a translation strategy, namely by introducing, inserting words or phrases which are not to be found in the original text, in order to offer an explanation. This strategy is meant to correct the linguistic and cultural discrepancies; through the extension of the source text are aimed elements of language, culture, civilisation, considered to be unknown to the reader (Minut \& Lihaciu, 2014, p. 98). The explanation takes the form of:

- gloss, i.e. mentioning another version for the translated word, a synonym in brackets;

- interpolation, i.e. mentioning other version for the translated word, introduced with the conjunction or.

Unlike the gloss, the interpolation "doesn't segment the reading, but the reader, on the other hand, cannot distinguish between the text's voice and the translator's voice” (Minuț \& Lihaciu, 2014, p. 98).

b) calques-words which are formed from the material of the target language and borrow the internal form and/or the meaning of the German foreign words. These are of three types:

- structural calque, through which a new word is formed by putting together two words or by derivation with prefixes or suffixes;

- semantic calque, through which a word is given a new meaning, after the German model;

- syntagmatic calque, through which a German phrase unit or compound word is calqued (Cujbă, 1999).

\section{Analysis of the translations of the criminal codes}

Next we will confine ourselves to a short analysis of the translations of the criminal codes in the first two periods ${ }^{1}$.

The first Austrian criminal code in force in Bukovina is the Theresian criminal code, Constitutio Criminalis Theresiana (1768), from which in Romanian was translated only a short version of the second part, in form of an abstract, with the title Publicație cuprinzind abaterile și pedepsele ce se vor aplica celor vinovați [Publication comprising the transgressions and the punishments to be applied to the guilty ones] (1780). In regard to the lexis, one can notice the use of common language, unspecialized at that time. Because in Romanian there did not exist any terms to designate a certain criminal quality, the translator puts to use some strategies, such as:

\footnotetext{
${ }^{1}$ For an analysis of the translations of the laws from German into Romanian in all legal matters, see Zup (2015b).
} 
a) explaining the German noun, which was usually abstract, through a subject sentence:

- cel ce va defäima pe Dumnezeu - Gotteslästerung (Art. 1);

- cel ce va schimba legea creștinească - Abfall von christlichen Glauben (Art. 2);

- cel ce va giura strîmb sau va strîca giurämîntul lui - Von falschen Schwüren, und Meineid (Art. 4);

- cel ce va curvi cu sîngele său - Von der Blutschand (Art. 15);

- cel ce va sili pre oare cineva cu sila spre curvie - Von der Nothzucht (Art. 16);

- cel ce va avea douămueri sau mai multe, sau muiarea doi bărbați - Von zweifacher Ehe/Doppelte Ehe (Art. 18).

b) using verbs derived from nouns or adjectives for the abstract German terms:

- un răzvrătitoriu şi zurbagiu - Von Aufruhen, und Tumulten (Art. 6);

- insurații sau măritații de vor curvi cu altul - Von dem Ehebruch (Art. 17);

Rarely there can be found in Romanian the abstract term equivalent to the German one:

- uciderea, rănirea și alte fapte de moarte - Von dem Todschlag, so im Getümmel, und Schlägeren unter vielen Leuten begangen wird (Art. 23);

- curvia de obște - von gemeiner Hureren (Art. 21).

In 1787 the Josephinian criminal code comes into force ${ }^{2}$, Allgemeines Gesetz über Verbrechen und derselben Bestrafung; the text was translated into Romanian by Ioan Budai-Deleanu and published in 1788 with the title Pravilă de obște asupra faptelor rele și a pedepsirii lor. Even from the title one can observe the archaism of the text: pravilă (Gesetz) - lege pentru popor; de obște - cetățenesc, oficial, used in this context for general, allgemein. Because in Romanian there did not exist any special term for Verbrechen (criminal offence), the translator introduces the phrase fapte rele, and for Verbrecher (criminal offender) - făcătoriu de rău criminălesc. In actual fact, in this context, the translator makes use of linguistic calques to render in Romanian legal realities for which there did not exist just yet a vocabulary. Also in the publication patent one can observe the frequent use of glosses:

- să să nimerească (chibzuiască) dreapta potrăvire (proporţie), p. 2 - das billige Ebenmaßzu treffen;

- intipărirea (lucrarea), p. 2 - Einbruck (intipărirea is a calque formed after the German term).

The fact that in this text appear Moldavian forms, such as $\breve{g}$ in agiunge or the form tatul determines Gheție (1975, p. 481) to assign it a particular place among the texts printed in Vienna in this period and to make the assumption that a Bukovinean would have collaborated in a way or another to the book's translation, revision or printing (probably Vasile Balș). In regard to the dialectal distinctions from the literary norms, the linguist ascertains the following phonetic distinctions:

- iá maintained in all words, for example încuiată (p. 75);

- $\hat{\imath}$ in minile, pîne (p. 25, 109);

- the labial consonants are almost without exception soft: să se lovească (p. 106), but să să scobască (p. 15);

- hard $s, z, t$, appear more frequently than in other texts: încredințază (p. 59), năsîlnică (p. 48), să săpreiuțască (p. 37), treizăci (p. 106);

- in general, $s, j(+e)$ are soft, but hard $s, j$ appear insistently: aşezate (p.78), grije (p. 71), inșelăciunii (p. 29), îșălătoare (p. 48);

- in regard to phonetisms of type slujęște (slujește) - slujaște, șépte (șepte) - șapte, there can be noticed a mixture of hard and soft utterances, the latter being more frequent: pășessste (p. 97), slujessste (p. 38), a șéptelea (p. 94), șaselea (p. 77);

- the form să hotăréşte (p. 129, 135);

- quite frequent use of the invariable possessive article $a$ : a (l) patriei (p. 27), a(le) statului (p. 37);

\footnotetext{
${ }^{2}$ For an analysis of the Josephinian criminal code from the perspective of legal studies and history of culture, see Zup (2015a).
} 
- verbal forms with remade dentals: să cadă (p. 112), să scoată (p. 115) and iotacisation forms: să rămîie (p. 57), să spuie (p. 28, 157), să scoaţă (p. 29);

- quite frequent forms ending in -ěie (-aie) at the present tense, third person singular and plural of the verbs a da and a lua: să (să, se) déie (p. 53), să iaie (p. 104);

- $m$ maintained in au rumptu (p. 91);

- hard utterance of $n$ in năsîlnică (p. 48);

- $n>r$ in amăruntul (p. 109);

and morphological:

- tată has the articulated form tatul (p. 59) (Gheție, 1975, p. 474-479).

The hardships met by the Romanian translators were underlined by Bals, who, by pointing out that some decrees were translated in such a manner that they cannot be understood by the Bukovinean population, shows the High Court of Justice in Vienna the poverty and the provocations of the Romanian legal language: "In jurisprudence exist terms for which in the country's language there are no words, but only equivalent phrases, which requires an exact definition of the words through those expressions, which can be conveyed only by a man who masters perfectly the language" ${ }^{3}$. This definition implied in most cases the calque of the German term, which meant the implementation of new legal realities to the Romanian legal thinking and style.

The hardships were doubled by the lack of a vocabulary of Romanian legal and administrative terminology at that time. In order to overcome these shortcomings, Vasile Bals, Ion Budai-Deleanu and Georg Oechsner print in 1787 a German-Romanian legal dictionary, whose title appears in the catalogue of Budai-Deleanu's library: Deutsch-Wallachisches Wörterbuch über Verbrechen [German-Wallachian Dictionary of Crimes]. A note from the proceedings of the Galicia's Aulic Chancellery from 1788 summarizes the decree for Galicia's government, in which the price of 25 kreutzers was set for the sale of a copy of a juridical book "über Verbrechen und Strafen in deutsch- und moldauischer Sprache" [on crimes and punishments in the languages German-Moldavian], sent to Lviv. Taking into consideration the price, we can conclude that the dictionary contained only a few pages. Unfortunately, no copy of this dictionary could be found, but we can evaluate its importance for the evolution of the Romanian legal language, because it offered some equivalents of the German and Latin terms, in an era in which, at European level, the legal language was mature, the elaboration of dictionaries being a common practice. Thus, also the Bukovinean translators integrated themselves in the tendency that could be observed at European level, that of drawing up aiding materials not only for the translator's work, but also for the more profound understanding of the legal texts, whose hermeneutics became more and more complex. Such dictionaries appeared some years back in Germany (De verborum que ad Jus civile pertinent significatione, Haale, 1743, or Eberhard J.H., Kritisches Wörterbuch über juristische Sachen, 1769-1772). We can conclude that Deutsch-Wallachisches Wörterbuch über Verbrechen paved the way for future Romanian legal dictionaries and glossaries, for example that published by Flechtenmacher \& Cuzanos (1815) in Iași, and, together with Budai-Deleanu's lexicon, for the dictionaries for German and Romanian which were printed at the beginning of the $19^{\text {th }}$ century: Kleines walachisch-deutsch und deutsch-walachisches Wörterbuch (1821) by Andreas Clemens, Wörterbuchlein deutsch und walachisches = Vocabularium nemțesc și românesc (1822, Sibiu) by Ioan Piuariu Molnar, Lesicon romanescu-latinesc-unguresc-nemțesc (1825, Budapest).

In 1804 comes into force a new criminal code, Gesetzbuch über Verbrechen und schwere Polizey-Uebertretungen. Its translation into Romanian, accomplished by Toma Moldovan and revised by Ioan BudaiDeleanu, was published in 1807 with the title Carte de pravilă ce cuprinde legele asupra faptelor răle și a călcălilor grele de poliție. The particularities of the Romanian text consist in the use of common, unspecialized terms, the inconsistency in the use of the terms, interpolations and calques (rodul pintecelui Leibesfrucht, Art. 128; fäcătoriu de criminal - Verbrecher, Art. 132).

In 1852 , as a result of the changes caused by the revolution from 1848 , a new amended and sup-

${ }^{3}$ Haus-, Hof- und Staats-Archiv, Wien, St. R., No. 8/1787, annex XIII, apud Protopopescu (1967), p. 102. 
plemented version of the criminal code comes into force: Das Strafgesetz über Verbrechen, Vergehen und Uebertretungen, die Strafgerichts-Competenz-Verordnungen und die Press-Ordnung vom 27. Mai 1852 für das Kaiserthum Oesterreich, translated into Romanian by Eudoxiu Hurmuzachi and published in 1853 with the title Codicele penale despre crimini, delipte și abateri, ordinăciunile despre competința județelor penali, și regulămîntul de tipariu din 27 mai 1852 pentru Imperiul Austriei. As it can be noticed from the title, this translation contains new specialized terms, because Hurmuzachi introduced many neologisms which compensated for the deficits of a legal language less specialized and on an inferior stage of evolution than the German one. By comparing it to the old penal code, it results that Strafgesetzbuch is translated now with codicele penale instead of carte de pravilă, and Verbrechen with crimini instead of fapte rele.

Although Gheție (1975, p. 531, 538-540), remarked that for the period 1836-1881, the Romanian legal literature in the territories which were part of the Habsburg Empire is "insignificant" - in spite of the publication of the civil and criminal procedure codes, of the constitutional acts-, makes some remarks regarding the dialectal differences which come up in the criminal code translated by Hurmuzachi:

- very rare cases of medial atonic $e$ changed into $i$ : aseminea (p. 10);

- hypercorrect (Latinized) methods of writing, with $e$ and $i$ after ț: ațițare (p. 103), țeri (p. 6);

- $j$ written $j+$ Latin $o, u$, and $\breve{g}$ is used to reproduce in writing jur and related words: impregiurări(le) (p. 12);

- hard $r$ alternates with soft $r$ in words of the category argintar, croitor: fäptorul (p. 12), tipăritorului (p. 204), vînzătorul (p. 14) - ajutoriu (p 13);

- forms with remade dentals:să prevadă (p. 42), să se pună (p. 7), să se scoată (p. 24);

- the order of the auxiliary $a$ at indicative past perfect third person is taken over from the German original: datu-s-a (p. 10);

- the form să deie (p. 13);

- $\breve{a}$ did not change into $\hat{\imath}$ in pănă (p. 6);

- ă maintained in năsip (p. 13);

- $e>a$ a in lăpădătură (p. 187), străin (p. 23);

- e maintained in prevegheare (p. 15);

- iu maintained in minciunoasă (p. 77);

- $n>r$ in amerință (p. 99).

Although Hurmuzachi introduces many new terms in the text from 1853, this does not lead to a greater clarity in comparison with the texts from 1788 and 1807, which is proven by the fact that only some of these terms succeeded in entering the modern Romanian language. One can observe that Eudoxiu Hurmuzachi makes use of interpolations in order to explain some German terms, by offering the second or even the third version with the means of the conjunction sau:

- violența publică sau pe față - Öffentliche Gewaltthätigkeit (Art. 76-100);

- rapină sau răpitoriă sau lotriă - Raub (Art. 190-196);

- abort sau lepădătură făcută - Abtreibung des Leibesfrucht (Art. 144-148).

The interpolation appeared rarely at Budai-Deleanu: duell sau combat (1788, Art. 89), război intre doi sau volnica ucidere (1807) - Zweikampfe.

The translators are inconsequent in the use of some legal terms, not only in the translations of the successive versions of the criminal code, but also within the same text: for example, öffentlich is translated in 1788 with vederat (with the meaning of vizibil) and in 1807 with obște (public).

From the comparative analysis of the translations, the conclusion can be drawn that when the German text is identic or very similar to that from the previous abrogated criminal code, the Romanian translator does not resort to the previous translation; moreover, he does not even make use of the same terms to designate the same concept, which could have led to many confusions, if German was not the official language. Although many fragments from the criminal code from 1853 are identic to those from the previous 
one, Hurmuzachi does not resort to the older translation. Moreover, from the following examples one can observe some neologisms introduced by him, in comparison to the language used by Budai-Deleanu:

- a comite (a crime) instead of a face for begehen;

- färă a ave facultate instead of nefiind volnic for unbefugt;

- in cerculăciune instead of umblătoriu for im Umlaufe;

- ginuină instead of drepți for echt;

- carcere instead of temniță for Kerker (neologism borrowed from German).

In regard to the explanation of neologisms, Hurmuzachi makes use of two strategies:

- the gloss: soții criminei (conculpați și complici) (Art. 5);

- the interpolation: cugetul s. propusul rău (Art. 1).

\section{Conclusions}

Our conclusions are in accordance with the theory developed by Coșeriu (1998, p. 9), i.e. the translator's competences did not concern only the first phase of the translation, the semantician one (the phase of understanding what the original text designates), in which the legal comprehension was essential, but also the second one, the onomasiological one, in which he had to find in the target language the meaning which would render exactly the designations identified in the original text. The shortcomings of a language on a stage of evolution inferior to the German one were compensated, at least partially, through various means. The translations are characterized by long sentences, with many determinations and intercalations, written under the influence of the German text, and an etymologic orthography. Not until the beginning of the $20^{\text {th }}$ century did the legal language, as rendered in the translations of the Austrian legislation, mature.

In the first period of the translations, the legal lexis is of a popular, traditional nature; the German language offered, from the point of view of semantics, the possibility of enriching (through calques) the old Romanian words, for example in Ioan Budau-Deleanu's translation fapte rele for infracțiune, făcător de rău for infractor. In the second period, German contributed to a great extent also to the introduction, fixing and semantical enriching of neological borrowings, which constitute the majority of the elements which make up the present Romanian legal terminology. In this regard, German could collaborate especially though its neological lexis, through the philosophical terms of Greek-Latin or Roman origin, comparable to those which entered our language from Latin, Greek, French and Italian (Jumugă, 1986, p. 41-46). The confrontation between tradition and innovation has as a result the coexistence of some aspects of archaic and popular character with linguistic innovations. Certainly, numerous specialized terms have multiple etymology, for example Romanian Avocat - Latin Advocatus, German Advokat, Italian Avvocato, French Avocat, our assertion being that these could have been borrowed rather from German, at least in the Bukovina area, because of the large number of translations into Romanian.

Introducing neologisms from German through the translations of the Austrian legislation was sustained and doubled in the second half of the $19^{\text {th }}$ century by the development of the faculties of law in Iași and Bucharest, where the professors, most of them having studied in German speaking countries, held lectures written after foreign models, among which also German, as it can be noticed from the bibliography, as well from the terminology used (Cujbă, 1999, p. 76).

Through the legal translations for the region Bukovina, but also through the direct access to the Austrian legal literature (for example, through the activity of the professor of law, translator and jurist from Iași Christian Flechtenmacher), the reforms during and after the reign of Emperor Joseph II are known also in the Romanian Principalities Moldavia and Wallachia. Thus, the Romanian jurists can assimilate the Josephinean and then the neoliberal principles, in order to try subsequently to adapt them to the local realities. We can ascertain that in the first half of the $19^{\text {th }}$ century, the translations of the Austrian legislation contribute to the overrun of the medieval practices of punishment and hearing, as well as of the class justice, but also to the integration in the Central European modern legal thinking. The Romanian 
legal reform, to which contributed also the understanding of the Austrian legal texts, facilitated in 1864 the coming into force of a new civil code after the French model, Code Napoléon. The translations of the Austrian legislation stand proof for the levels on which the modernisation process took place in the context of the specific relationship between the centre Vienna and the periphery, between the metropolis and the province, having to a certain extent also an impact on the Romanian legal language.

\section{Bibliography}

\section{A. Sources}

${ }^{* * *}$ Publicație cuprinzind abaterile și pedepsele ce se vor aplica celor vinovați, Joseph Edlen von Kurzbek, Viena, 1780.

*** Pravilă de obște asupra faptelor rele și a pedepsirii lor, translated into Romanian by Ioan Budai-Deleanu, Joseph Edlen von Kurzbek, Viena, 1788.

*** Carte de pravilă ce cuprinde legele asupra faptelor răle și a călcălilor grele de poliție, translated into Romanian by Toma Moldovan and Ioan Budai-Deleanu, P. Ekhard, Cernăuți, 1807.

*** Codicele penale despre crimini, delipte și abateri, ordinăciunile despre competința județelor penali, și regulămîntul de tipariu din 27 mai 1852 pentru Imperiul Austriei, translated into Romanian by Eudoxiu Hurmuzachi, Hof- und Staatsdruckerei, Viena, 1853.

\section{B. References}

Coșeriu, E. (1998). Relația dintre lingvistica contrastivă și traducere, in "Analele Științifice ale Universității «Alexandru Ioan Cuza» din Iași. Secțiunea Limbi și literaturi străine”, translated by Casia Cujbă, Editura Universitățiii „Alexandru Ioan Cuza” Iași, p. 5-20.

Cujbă, C. (1999). Influența germană asupra vocabularului limbii române literare contemporane, Paideia, București.

Flechtenmacher, C. \& Cuzanos, A. (1815). Scară a cuvintelor celor streine și celor fãcute din firea limbii, care cuvinte au cerut neapărat trebuința a se metabirisi in alcătuirea prevililor, Mitropolia Moldovei, Iași.

Gheție, I. (1975). Baza dialectală a românei literare, Editura Academiei, București.

Jumugă, M.G. (1986). Rumänische Einflüsse in den deutschen Siedlungsmundarten und in der deutschen Umgangssprache der Bukowina, în Interferențe culturale româno-germane. Contribuții ieșene de germanistică, IV, ed. by Andrei Corbea and Octavian Nicolae, Editura Universității, Iaşi, p. 41-46.

Kremnitz, G. (1994). Gesellschaftliche Mehrsprachigkeit. Institutionelle, gesellschaftliche und individuelle Aspekte. Ein einführender Überblick, Braumüller, Viena.

Minuț, A.M. \& Lihaciu, I. (2014). Interpolarea ca strategie de traducere a Istoriei universale adecă de obște, care cuprinde în sine intîmplärile veacurilor vechi, versiune în limba română de Ioan Piuariu Molnar, in Impulsul iluminismului in traduceri româneşti din secolul al XVIII-lea, ed. by Eugenia Dima and Andrei Corbea-Hoișie, Editura Universității „Alexandru Ioan Cuza" Iași, p. 91-136.

Protopopescu, L. (1967). Noi contribuții la bibliografia lui Ion Budai-Deleanu. Documente inedite, Editura Academiei, București.

Zup, I. (2015a). Die Übersetzungen der Habsburgischen Strafgesetzbücher ins Rumänische, in "ANADISS. Journal of the Discourse Analysis Research Centre", iss. 19, p. 187-198.

Zup, I. (2015b). Traducerile legislației austriece in Bucovina habsburgică (1775-1918), Editura Universității „Alexandru Ioan Cuza" Iași. 